談 話 室

\section{PSA-01 (Practical Surface Analysis 2001)}

\author{
田沼繁 夫 \\ 物質 ·材料研究機構 材料研究所 \\ 函 305-0047 茨城県つくば市千現 1-2-1
}

(2002年 1 月 11 日)

\section{PSA-01 (Practical Surface Analysis 2001)}

\section{Shigeo TANUMA}

Materials Engineering Laboratory National Institute for Materials Science 1-2-1 Sengen, Tsukuba, Ibaraki 305-0047

(Received January 11, 2002)

実用表面分析に関する第 2 回国際会議 PSA-01 が 2001 年 11 月 19 日から 21 日までの 3 日間にわたり奈良県奈 良市新公会堂で開かれた。参加者は 12 か国からおよ光 100 名であった。SIMS や TEM 等に関する国際会議が前 週に同じ会場で開かれているので, この「実用表面分析」 PSA-01 は電子分光中心の会議となった。光れも実用 的・実際的な分野でこれだけの人数が集まる会議は他に はないと思われる。

この実用表面分析に関する国際会議 PSA は第 1 回が 1998 年 11 月に奈良で開かれ, 今回が 2 回目である。こ の会議は表面分析研究会 (SASJ) 主催のものであり, 兴のユニークな点は全てが会員のボランティアで運営さ れているところにある。今回も弚の流れに沿って会員の ボランティアで会議は運営された。会議は 11 月 18 日 (日) の昼のエクスカーションから始まり, 夕方にはウ エルカムパーティーが開かれた。エクスカーションは法 隆寺ツアーであり，海外からの方を中心におよ光 60 人 ほどが参加された。天気は奈良の新公会堂ではまずまず であったが, 法隆寺では短い時間ではあるが, 通り雨に あったと聞いている。しかし, 弚れ以外はとても良かっ たと，この会議に参加したNIST の Powell 博士やNPL のSeah 博士からお聞きした。もちろん他の参加者も同 樣の感想であった。

夕方 6 時から開かれたウエルカムパーティーは, 月曜 日のポスターを貼る時間としても便利であったためかと ても盛況であった。予定の終了時刻である 8 時を過ぎて も残っている方が多く，とても好評であった。
会議は翌日 8 時 45 分に組織委員長である吉原博士 (NIMS) の開会挨拶ではじまり，続いて NPL の Seah 博 士の AES と XPS の定量に関するプレナリートークがあ った。この初日は午前中にはこの講演を含め 5 件の口頭 発表 (装置および測定法の開発) があった。Seah 博士 の講演は彼の提唱する「マトリックス感度係数法」に関 するものであるが， REELS を用いたバックグラウンド の差し引き等から始まり，実用分析の正確さを格段に向 上させるものであり，示唆に富むものであった。午後は この会議のメインであるポスターセッションである。ポ スターの件数はおよ光 50 件であった。ポスター展示は 3 時から 6 時までであるが，これに先立ち 1 人 2 分間 (OHP 2 枚以内) のポスター発表に対するプレゼンテー ションが行われた。この会議では最優秀ポスター(最も 人気のあった！）に対して表面分析研究会から Powell 賞か贈られることもあり，おもしろい発表が多かった。 この会議は「実用」であることを第 1 にしているもので あるが, 非常に基礎的な絶対量計測の話や物理パラメー タの測定から日常的な表面分析で重要な試料表面の污染 や酸化を空気中で如何に防ぐかといった話や，さらに SOR 光を用いた表面分析までの幅広い分野をカバーし ていた。

ポスターセッション終了時に行われた投票 (参加者は 乥れ午れ 1 票を持つ) では, TDK の柳内博士がダント ツの票を集め，みごと Powell 賞を射止めた。この投票 は国内会議として開かれるPSAでも毎年行われ，今回 が第 7 回目である。柳内博士は毎年，この投票では上位 に食い込んでいたが，今回は見事にトップとなり念願を 果たした。受賞した発表のタイトルは Practical Procedure for Protecting Changes of Surface Condition in the Air” であ る。この発表は分析試料を空気中で保管する場合に如何 にして污染や酸化を簡便な方法て防ぐかについて検討し たものである。2つの試料の表面を重ね合わせて保管す る方法 (Same Surface Contact Method, SSCM と名付けた) を考案し，光の有効性を実証した。この方法は簡便であ り，実用的である。

翌 2 日目は基礎と標準化の講演が行われた。弾性散乱 効果やバックグラウンド処理, IMFP と PEAL の比較の 話が基礎的ではあるが, 実用的にも価值の高いものであ つた。さらに, Baer 博士 (Pacific Northwest NL) の AES, XPS による絶縁物分析の話は興味を引いた。標準に関 しては名工大の後藤教授のセルフコンシステントなエネ ルギーキャリブレーションの講演や小島博士 (産総研) の表面分析標準試料の講演がなされた。これら午前中の 
セッションでは, 議論が盛り上がり大幅に時間が超過し てしまった。

午後は Seo 教授 (Chunbuk Univ.) のフェルミレベル の計測の話を始めとして, XPS の装置関数や全反射 XPS , 高精度角度分解 SOR-XPS の装置開発等の講演が あり，議論は大いに盛り上がった。しかし，午前中の時 間超過がたたり，議論を時間でうち切らざるを得ず残念 であった (の点は実行委員長であつた筆者の反省点で ある)。

この日の夜はバンケットがあり, 奈良駅に近い三井ガ ーデンホテルで盛大に開かれた。これに先立ち Powell 賞の表彰式が厳肃に行われた。受賞者である柳内博士に Powell 賞のお名前をいただいた当の Powell 博士 (NIST) より受賞盾と副賞が渡された。パーティは料理もすばら しく，またお酒も吟味されたものが弚ろい好評であった。 和やかな歓談はバンケット終了後も続き, なかなか会場 を閉じることができず,担当者は大変だったようである。 翌 3 日目も好天に恵まれた。多くの参加者はホテルか
ら奈良公園を散歩しながら会場に到着した。この日の講 演は午前中は德高教授 (鳥取大) のSOM MAP の招待 講演をはじめとするデー夕処理 (弚の他には深さ方向分 析やXPS のイメージング等) であった。午後は実用材 料分析の講演が行われた。この中で Applied Material の Brundle 博士の講演は実際的実用的で大変に示唆に富む ものであった。また，他のたくさんの講演に対する彼の 色々なコメントは実用性を常に意識したものであり，こ の会議には大変にうさわしいものであったと思われた。

次回のこのPSA 国際会議は 3 年後の 2004 年に韓国で 開かれるとのことである。このような実用的かつ実際的 な表面分析の国際会議は他にみられないものであり，日 本企業の研究者や技術者が中心になてボランティアワ 一クでこれを支えていることはとてもすばらしいことで ある。次回もたくさんの方々がこの会議に参加し, 議論 を楽しむことを期待している。最後に，この会議のProceedings は表面分析研究会の会誌 Journal of Surface Analysis Vol. 9 に掲載される予定である。 